\title{
Henning Biermann: Verwaltungsmodernisierung in Mecklenburg-Vorpommern, Grundlagen, Entwicklungen, Perspektiven; Schriften zum Öffentlichen Recht
}

\author{
Band 1193, Duncker \& Humblot, Berlin, 2011
}

\author{
Juergen G. Backhaus
}

Published online: 19 February 2012

(C) Springer Science+Business Media, LLC 2012

Among the certainties of politics in the new federal states of Germany is the regular call for reorganization, implying ever bigger public structures in a bid for more efficiency.

Helmut Seitz (cited on page 729) played an active role in these processes, producing expert opinions for different new federal states, basically always the same opinion irrespective of the structure of the state for which he was working. Although nobody has ever realized such savings or efficiency improvements, the quest goes on which begs the question of why?

In stunning sincerity, the now minister for social affairs of the free state of Thuringia in a meeting of the select committee on the reorganization of state structures stated that the purpose of creating ever bigger structures was to create better career opportunities for public employees.

Although the constitutional court of the state of Mecklenburg-Pomerania criticized one such reorganization attempt in the state, citing the democracy deficit such large structures would entail, this work fails to look at the underlying interests in resulting democracy deficits.

It is a dissertation of the University of Rostock in law, which was designated the best of the year of 2009 and received a prize of the Hoppe Foundation.

The large literary basis lacks any reference to either public choice or law and economics or the economic theory of bureaucracy and thus leaves the avid reader rather empty-handed.

\footnotetext{
J. G. Backhaus $(\bowtie)$

Krupp Chair in Public Finance and Fiscal Sociology, University of Erfurt, Nordhäuser Strasse 63, 99089 Erfurt, Germany

e-mail: juergen.backhaus@uni-erfurt.de
} 